\title{
ANALYSIS OF PROBLEMS, CONSEQUENCES AND SOLUTIONS FOR BIM APPLICATION IN RECONSTRUCTION PROJECTS
}

\author{
Darius MIGILINSKAS ${ }^{\mathrm{a}}$, Miroslavas PAVLOVSKIS ${ }^{\mathrm{a}}$, Irina URBA $^{\mathrm{b}}$, Viačeslav ZIGMUND ${ }^{\mathrm{b}}$ \\ ${ }^{a}$ Department of Construction Technology and Management, Faculty of Civil Engineering, \\ Vilnius Gediminas Technical University, Sauletekio al. 11, LT-10223 Vilnius, Lithuania \\ ${ }^{b}$ Department of Reinforced Concrete and Masonry Structures, Vilnius Gediminas Technical University, \\ Sauletekio al. 11, LT-10223 Vilnius, Lithuania
}

Received 29 Jun 2017; accepted 13 Aug 2017

\begin{abstract}
The main aim of analysis presented in this paper is based on the complex evaluation of Building Information Modelling (BIM) application and decision support in reconstruction projects. The reconstruction projects face the high level uncertainty during implementation mostly due inappropriate information management, insufficient quality control and low competence of participants. The application of advanced Computer-Aided tools such as BIM uses both with advanced Information and Communication Technologies (ICT) can be the way to solve the problems of reconstruction projects. The fourteen reconstruction projects have been analysed and the list of thirteen main problems has been identified. The pair wise judgment of problems has been made based on in the expert survey using the Analytic Hierarchy Process (AHP) method. The occurrence, influence to project and significance of the problems have been calculated and were prioritised according to the importance and consequences. After the complex analysis of problems, it is suggested to use combined list of solutions of the BIM tool application in reconstruction projects to support decision making process.
\end{abstract}

Keywords: Building Information Modelling, reconstruction projects, BIM uses, decision support.

\section{Introduction}

The implementation of construction projects faces a lot of uncertainties, unforeseen situations, which leads to various ambiguities and can crucially influence the success of the project. There is no significant difference in the sources of problems during implementation of ordinary construction project (Eadie et al. 2013) or implementation of reconstruction projects (Pavlovskis et al. 2016). Reconstruction projects face the same problems as ordinary construction projects and the biggest problems are information and energy efficiency (Barbosa et al. 2016; Migilinskas et al. 2016). The challenges in reconstruction projects are mostly connected with the high-level uncertainty or lack of initial project information, inappropriate information management during implementation, insufficient work quality control on site and low competence of project team members and other participants (Sun et al. 2015).

The reconstruction projects need to be evaluated from perspective of whole duration of the project. The actions, processes and problems which would influence the effectiveness of design, manufacturing, building and maintenance need to be analysed through the whole lifecycle of the project ( $\mathrm{Lu}$ et al. 2016). It is suggestable firstly to identify the most significant technical, organi- zational and managerial problems of reconstruction projects, then to analyse tools and actions that could help to prevent the problems and to increase the effectiveness of the projects (Di Giuda et al. 2015). Due to fast development of advanced Computer-Aided technologies in construction industry, project participants clearly understand the benefits from their experience and best practices (Migilinskas, Ustinovichius 2006; Sun et al. 2015; Lam et al. 2017). The application of various tools from the list of advanced Information and Communication Technologies (ICT) such as modern photogrammetry, laser scan, real 3D modelling and other BIM uses (Mill et al. 2013; Pepe et al. 2016) can be treated as solution to eliminate the problems in most of reconstruction projects (Popov et al. 2010; Ustinovichius et al. 2017).

Building Information Modelling (BIM) as advanced Computer-Aided technology has been increasingly applied in new construction projects, but it is still rarely used in building refurbishment and reconstruction projects (Volk et al. 2014; Zhao 2017). The implementation of reconstruction project suffers from a set of specific problems related with technical, organizational, information and project management problems (Migilinskas et al.

Corresponding author: Darius Migilinskas

E-mail: darius.migilinskas@vgtu.lt 
2016; Barbosa et al. 2016). The project participants need to solve this kind of multiple problems and need to make the most effective decision (Kutut et al. 2014; Zavadskas et al. 2016). Therefore, BIM is suggested to be applied to support the decision-making process.

The aim of this research is firstly to identify the most significant technical, organizational and managerial problems in reconstruction projects, then to analyse consequences and suggest tools and actions that could help to prevent the problems and to increase the effectiveness of the projects, and finally suggest application of BIM in reconstruction projects.

\section{Literature review}

Various scientists have noticed, what one of the main requirements to initiate design and construction of any type of reconstruction project is the earliest start of sharing information with projects promoters, designers, contractors, engineers and other project participants (Volk et al. 2014; Di Giuda et al. 2015; Xian, Chen 2015). It is the biggest source of the problems and it is necessary to have disciplined audited data exchange process which should be transparent and controlled because it is necessary for effective procurement procedures of the project. The Most common mistakes during these procedures as incorrectly estimated contract value, overestimation of materials and workforce, underestimating the sustainable development indicators, resulting in unsuitable purchase option (Pavlovskis et al. 2016). This occurs due to the lack of reliable information and leads to the uncertainty, when the project design and bill of quantities are wrong or inaccurate, which requires extra effort for checking reliability. Often inaccuracies in the design documentation occur due to the careless work of designers and sometimes even rounded numbers or irregularities compose and distort the project (Popov et al. 2010; Lin et al. 2016a).

Moreover, competitions are often organized by inexperienced persons, who find it difficult to evaluate all financial, technological, environmental and sustainable development indicators, resulting in assessing proposals based on the lowest price. The cheapest option may not always be the most economical choice due to the importance of the production technical quality and the lifetime of the construction (Pavlovskis et al. 2016). To guarantee themselves a sufficient amount of work and to remain competitive, contractors often reduce the competitive price, hoping to reduce their costs and this often leads to reduced quality of work. When customers choose the contractor based on the lowest price principle, they risk encountering major problems and losses during long maintenance of the buildings (Lin et al. 2016b).

To avoid inaccuracies, it is suggestable to use BIM technologies for construction, reconstruction and even heritage projects estimated calculations during the preprocurement phase (Di Giuda et al. 2015; Zhao 2017). BIM software prevents from wasting time for preliminary estimate of the project - the program carries out the calculations and can generates reports automatically. The construction costs are quickly calculated, whereas their relationship to estimate calculation program allows to increase the accuracy of the list of purchases and to prevent unfair competitions (Popov et al. 2010).

The BIM model of building called 4D model is a designed building BIM model plus construction time with information about the necessary resources for the construction. Constructional building BIM model is used for the construction process planning and management of works in the timeline, using the information posted in the project BIM model database (Migilinskas, Ustinovichius 2006; Brito, Ferreira 2015). Optimized procedures with BIM model can help to avoid downtime, wasteful use of materials, delayed transport and result reduced environmental impact (Xian, Chen 2015). Combining the time planned three-dimensional model with the economic indicators, cash flows can be estimated at all stages and parts of construction. BIM price model - the so-called 5D model, is the price of materials and products, combined with parametric objects, together with the price of resources - manpower, machinery and materials, broken down by production time with production technologies virtually and in real life (Popov et al. 2010). BIM building model, transferred into service, can be used to manage the building in subsequent stages of its life cycle - design, construction, maintenance, reconstruction and demolition (Migilinskas, Ustinovichius 2006; Lu et al. 2016). Operational building model (Facility Management), often called the $6 \mathrm{D}$ model, due to the introduction of qualitative indicators (e.g., energy efficiency, living comfort, cost optimization, etc.) it's essence is the large quantities of continuously recorded, virtually accessible and operational information. It is designed for the management of all communications systems in the building, for planning the building maintenance costs (Ustinovichius et al. 2017), for monitoring the state of the equipment and maintenance of its technical conditions to ensure the necessary comfort and energy balance level of the building (Di Giuda et al. 2015; Rasiulis et al. 2015; Migilinskas et al. 2016).

\section{Methodology of analysis}

The fulfil the aim of this research the Lithuanian case studies of reconstruction projects, built in a period of 1950-1981 and reconstructed in the last 5 years, have been analysed to identify the list of problems and solution for decision making support in reconstruction projects. In the beginning of the Study stage the selection of reconstruction projects was made and after compatibility analysis the list of over 30 (thirty) projects was shorted to 14 (fourteen) projects of acceptable buildings in Lithuania. All projects were investigated and list of 13 (thirteen) main problems was selected. The survey with evaluation of experts using AHP method was done and the results of the Calculation stage short structured data were delivered to the Analysis stage to prepare Solutions. 


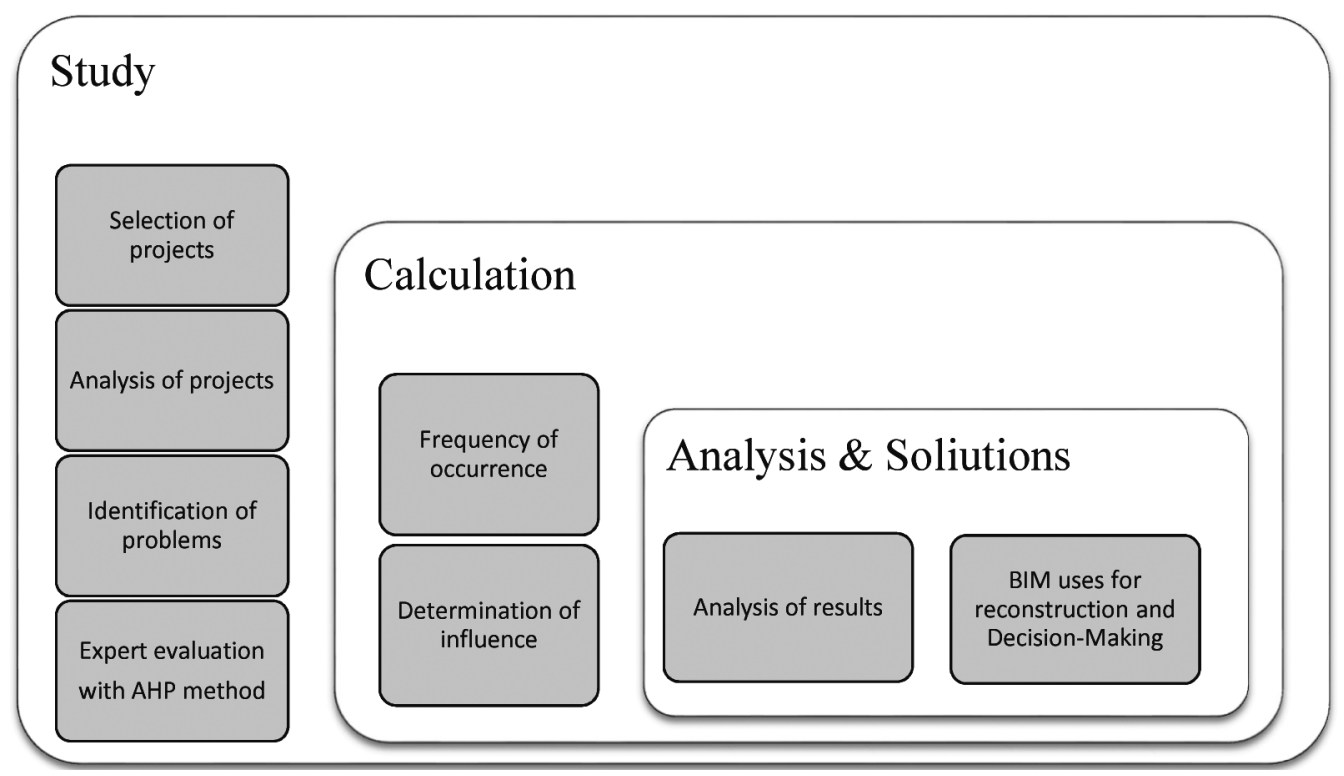

Fig. 1. Methodology of analysis

The research has been done according to the algorithm (see Fig. 1). The aim of this analysis is based on methodology described in three main stages such as Study, Calculation and Analysis \& Solutions:

- A set of common problems occurring during the reconstruction was identified and analysed on the ground of 14 case studies;

- The information collection methods: meeting with project managers, contacting by e-mail or by phone. Before comparing and analysing the data, information about the occurred problems was received by contacting contractor and representatives of designers who participated in these projects;

- The set of 13 main problems was identified;

- After detailed analysis of the projects and the gathered information, the frequency of occurrence of problems in the analysed projects was represented in percentage;

- The impact of each problem on the project was defined by using expert evaluation method and applying AHP (Analytic Hierarchy Process) that is one of available decision-making methods (Saaty 1980; Saaty et al. 2005). Experts were selected from practitioners and academicians related to project management (Erdogan et al. 2017). They were asked to compare and to evaluate the identified problems by using nine-point scale, shoving the intensity of importance. Survey results were treated according to Saaty's methodology;

- After analysing statistical data and expert evaluation results, significance of problems was estimated. Influence to project scores was normalized and multiplied by frequency of occurrence of problems. Problems significance was expressed in percentage (Table 5);
- Data structuration was performed, afterwards tools and actions that could help to prevent the problems and to increase the effectiveness of the projects were analysed. As a result, proposals related to BIM uses were introduced to overcome the major problems that are faced while implementing reconstruction projects.

\section{Application of Analytic Hierarchy Process method}

To support evaluation and selection processes in engineering, formal decision-making methods can be used. A great number of works applying diverse Multiple-Criteria Decision-Making (MCDM) techniques for engineering problems have been published recently (Zavadskas et al. 2016). The Analytic Hierarchy Process (AHP) is a multicriteria decision making (MCDM ) method that helps a decision-maker faced with complex problems that contain multiple conflicting and subjective criteria was originally developed in 1980 by Prof. Thomas L. Saaty. It is an effective tool for dealing with complex decision making, and may aid the decision maker to set priorities and make the best decision. By reducing complex decisions to a series of pairwise comparisons, and then synthesizing the results, the AHP helps to capture both subjective and objective aspects of a decision. In addition, the AHP incorporates a useful technique for checking the consistency of the decision maker's evaluations, thus reducing the bias in the decision making process (Saaty et al. 2005; Kutut et al. 2014).

The first step in the AHP procedure is to make pair wise comparisons between each criterion.

When it is needed to complete comparison matrix, the second step is to normalize the matrix and calculation of average value for calculation of consistency vector:

$$
\lambda_{\max }=\sum_{i=1}^{n} C v_{i j} .
$$


Calculation the consistency index $(C I)$ :

$$
C I=\left(\lambda_{\max }-n\right) /(n-1),
$$

where: $\lambda_{\max }-$ largest eigenvalue; $n$ - size of comparison matrix.

The final stage is to calculate a Consistency Ratio $(C R)$ to measure how consistent the judgements have been relative to large samples of purely random judgements. If the $C R$ is smaller or equal to $0.1(10 \%)$, the inconsistency is acceptable and if the $C R$ is equal or greater than $0.1(10 \%)$ the judgements are untrustworthy because they are too close for comfort to randomness and the exercise is valueless or must be repeated. It is easy to make a minimum number of judgements after which the rest can be calculated to enforce a perhaps unrealistically perfect consistency ratio $(C R)$. The final consistency ratio, if the evaluations are sufficiently consistent, is calculated as the ratio of the $C I$ and the random index $(R I)$, as indicated (Saaty 1980):

$$
C R=\frac{C I}{R I}
$$

\section{Description of expert survey and results}

List of problems from evaluation of the projects:

- P1 Problem - The documentation of the reconstructed building is out of date or not-existent;

- P2 Problem - Due to cost savings a feasibility study is not completed, technical and detail design is arranged in careless way;

- P3 Problem - The technical staff of Client are unqualified and incompetent (low skill and knowledge level);

- P4 Problem - Long duration of procurement and purchasing procedures takes long time;
- P5 Problem - Every project is being coordinated involving a number of participants;

- P6 Problem - Unqualified and incompetent design team, unable to evaluate time of design works;

- P7 Problem - There is no information continuity;

- P8 Problem - Incompetent contractor team, do not evaluated complexity and continuity of works;

- P9 Problem - The bad preparation of technical design;

- P10 Problem - Work repair during construction;

- P11 Problem - Delay in Decision making;

- P12 Problem - Extension of project execution time;

- P13 Problem - Correction of errors during warranty period.

The AHP based survey data and calculated data are presented in Tables 1, 2 and 3 as well as in Figure 2.

In the expert comparison matrix presented in Table 1, the consistency index $\mathrm{CI}$ value is calculated by using the Eqn (2). Then, the concordance ratio $C R$ is obtained by dividing

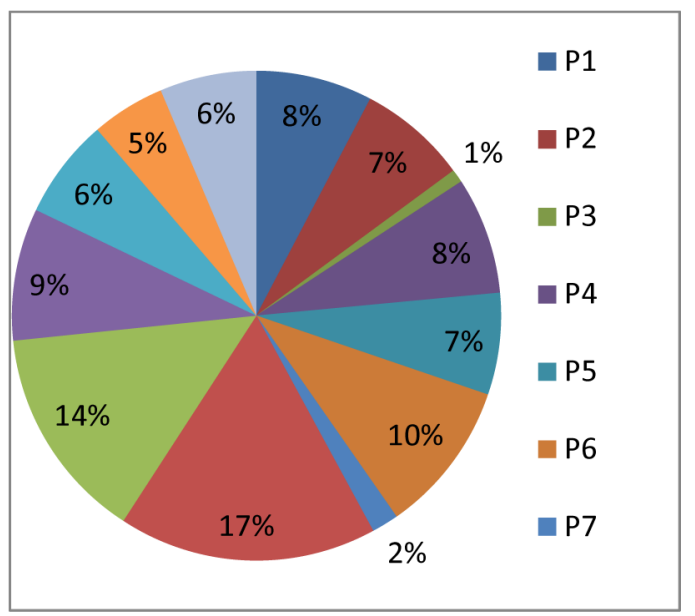

Fig. 2. Problem significance (Normalized values of criteria, \%)

\begin{tabular}{|c|c|c|c|c|c|c|c|c|c|c|c|c|c|}
\hline & $\mathrm{P} 1$ & P2 & P3 & $\mathrm{P} 4$ & P5 & P6 & P7 & P8 & P9 & P10 & P11 & $\mathrm{P} 12$ & P13 \\
\hline P1 & 1.000 & 3.000 & 2.000 & 2.000 & 1.000 & 0.333 & 0.333 & 0.333 & 0.333 & 2.000 & 3.000 & 0.250 & 2.000 \\
\hline P2 & 0.333 & 1.000 & 1.000 & 0.500 & 0.333 & 0.200 & 0.200 & 0.160 & 0.250 & 0.250 & 0.500 & 0.250 & 0.250 \\
\hline P3 & 0.500 & 1.000 & 1.000 & 0.333 & 0.333 & 0.250 & 0.200 & 0.200 & 1.000 & 0.250 & 1.000 & 0.250 & 0.333 \\
\hline P4 & 0.500 & 2.000 & 3.000 & 1.000 & 3.000 & 1.000 & 3.000 & 1.000 & 1.000 & 2.000 & 3.000 & 1.000 & 1.000 \\
\hline P5 & 1.000 & 3.000 & 3.000 & 0.333 & 1.000 & 1.000 & 1.000 & 0.500 & 1.000 & 1.000 & 5.000 & 0.500 & 0.400 \\
\hline P6 & 3.000 & 5.000 & 4.000 & 1.000 & 1.000 & 1.000 & 3.000 & 0.500 & 1.000 & 0.500 & 2.000 & 0.500 & 0.333 \\
\hline P7 & 3.000 & 5.000 & 5.000 & 0.333 & 1.000 & 0.333 & 1.000 & 0.333 & 0.500 & 0.333 & 1.000 & 0.200 & 0.500 \\
\hline P8 & 3.000 & 6.250 & 5.000 & 1.000 & 2.000 & 2.000 & 3.000 & 1.000 & 2.000 & 3.000 & 2.000 & 0.500 & 1.000 \\
\hline P9 & 3.000 & 4.000 & 1.000 & 1.000 & 1.000 & 1.000 & 2.000 & 0.500 & 1.000 & 1.000 & 2.000 & 1.000 & 0.500 \\
\hline P10 & 0.500 & 4.000 & 4.000 & 0.500 & 1.000 & 2.000 & 3.000 & 0.333 & 1.000 & 1.000 & 2.000 & 0.500 & 0.500 \\
\hline P11 & 0.333 & 2.000 & 1.000 & 0.333 & 0.200 & 0.500 & 1.000 & 0.500 & 0.500 & 0.500 & 1.000 & 1.000 & 0.250 \\
\hline P12 & 4.000 & 4.000 & 4.000 & 1.000 & 2.000 & 2.000 & 5.000 & 2.000 & 1.000 & 2.000 & 1.000 & 1.000 & 2.000 \\
\hline P13 & 0.500 & 4.000 & 3.000 & 1.000 & 2.500 & 3.003 & 2.000 & 1.000 & 2.000 & 2.000 & 4.000 & 0.500 & 1.000 \\
\hline TOTAL & 20.668 & 44.250 & 37.001 & 10.333 & 16.367 & 14.620 & 24.734 & 8.360 & 12.583 & 15.833 & 27.500 & 7.450 & 10.066 \\
\hline
\end{tabular}

Table 1. Initial matrix of the problem pair comparison with AHP method 
Table 2. Normalised matrix of the problem pair comparison with AHP method

\begin{tabular}{c|c|c|c|c|c|c|c|c|c|c|c|c|c|c|c}
\hline & P1 & P2 & P3 & P4 & P5 & P6 & P7 & P8 & P9 & P10 & P11 & P12 & P13 & Sum & Average \\
\hline P1 & 0.048 & 0.068 & 0.054 & 0.194 & 0.061 & 0.023 & 0.013 & 0.040 & 0.026 & 0.126 & 0.109 & 0.034 & 0.199 & 0.995 & 0.06626 \\
\hline P2 & 0.016 & 0.023 & 0.027 & 0.048 & 0.020 & 0.014 & 0.008 & 0.019 & 0.020 & 0.016 & 0.018 & 0.034 & 0.025 & 0.288 & 0.02187 \\
\hline P3 & 0.024 & 0.023 & 0.027 & 0.032 & 0.020 & 0.017 & 0.008 & 0.024 & 0.079 & 0.016 & 0.036 & 0.034 & 0.033 & 0.374 & 0.02834 \\
\hline P4 & 0.024 & 0.045 & 0.081 & 0.097 & 0.183 & 0.068 & 0.121 & 0.120 & 0.079 & 0.126 & 0.109 & 0.134 & 0.099 & 1.288 & 0.09913 \\
\hline P5 & 0.048 & 0.068 & 0.081 & 0.032 & 0.061 & 0.068 & 0.040 & 0.060 & 0.079 & 0.063 & 0.182 & 0.067 & 0.040 & 0.891 & 0.07099 \\
\hline P6 & 0.145 & 0.113 & 0.108 & 0.097 & 0.061 & 0.068 & 0.121 & 0.060 & 0.079 & 0.032 & 0.073 & 0.067 & 0.033 & 1.058 & 0.08540 \\
\hline P7 & 0.145 & 0.113 & 0.135 & 0.032 & 0.061 & 0.023 & 0.040 & 0.040 & 0.040 & 0.021 & 0.036 & 0.027 & 0.050 & 0.763 & 0.05946 \\
\hline P8 & 0.145 & 0.141 & 0.135 & 0.097 & 0.122 & 0.137 & 0.121 & 0.120 & 0.159 & 0.189 & 0.073 & 0.067 & 0.099 & 1.606 & 0.12567 \\
\hline P9 & 0.145 & 0.090 & 0.027 & 0.097 & 0.061 & 0.068 & 0.081 & 0.060 & 0.079 & 0.063 & 0.073 & 0.134 & 0.050 & 1.029 & 0.08164 \\
\hline P10 & 0.024 & 0.090 & 0.108 & 0.048 & 0.061 & 0.137 & 0.121 & 0.040 & 0.079 & 0.063 & 0.073 & 0.067 & 0.050 & 0.962 & 0.07602 \\
\hline P11 & 0.016 & 0.045 & 0.027 & 0.032 & 0.012 & 0.034 & 0.040 & 0.060 & 0.040 & 0.032 & 0.036 & 0.134 & 0.025 & 0.534 & 0.04242 \\
\hline P12 & 0.194 & 0.090 & 0.108 & 0.097 & 0.122 & 0.137 & 0.202 & 0.239 & 0.079 & 0.126 & 0.036 & 0.134 & 0.199 & 1.764 & 0.13035 \\
\hline P13 & 0.024 & 0.090 & 0.081 & 0.097 & 0.153 & 0.205 & 0.081 & 0.120 & 0.159 & 0.126 & 0.145 & 0.067 & 0.099 & 1.448 & 0.11246 \\
\hline
\end{tabular}

Table 3. The problem evaluation summary

\begin{tabular}{l|l|l|l|l|l|l}
\hline & Expert 1 & Expert 2 & Expert 3 & Expert 4 & Expert 5 & \multicolumn{1}{|c}{ Average } \\
\hline P1 & 0.04489 & 0.07328 & 0.06626 & 0.024487 & 0.02383 & $\mathbf{0 . 0 4 6 5 5}$ \\
\hline P2 & 0.03142 & 0.02086 & 0.02187 & 0.010713 & 0.06609 & $\mathbf{0 . 0 3 0 1 9}$ \\
\hline P3 & 0.04231 & 0.02189 & 0.02834 & 0.041258 & 0.104098 & $\mathbf{0 . 0 4 7 5 8}$ \\
\hline P4 & 0.04899 & 0.09940 & 0.09913 & 0.032314 & 0.071483 & $\mathbf{0 . 0 7 0 2 6}$ \\
\hline P5 & 0.06258 & 0.07467 & 0.07099 & 0.02344 & 0.030142 & $\mathbf{0 . 0 5 2 3 6}$ \\
\hline P6 & 0.11128 & 0.09083 & 0.08540 & 0.056665 & 0.047652 & $\mathbf{0 . 0 7 8 3 6}$ \\
\hline P7 & 0.05383 & 0.05497 & 0.05946 & 0.033955 & 0.041636 & $\mathbf{0 . 0 4 8 7 7}$ \\
\hline P8 & 0.12016 & 0.14759 & 0.12567 & 0.228182 & 0.043922 & $\mathbf{0 . 1 3 3 1 0}$ \\
\hline P9 & 0.16125 & 0.07355 & 0.08164 & 0.166913 & 0.160472 & $\mathbf{0 . 1 2 8 7 6}$ \\
\hline P10 & 0.03349 & 0.07286 & 0.07602 & 0.122895 & 0.034473 & $\mathbf{0 . 0 6 7 9 5}$ \\
\hline P11 & 0.16955 & 0.03801 & 0.04242 & 0.063279 & 0.287998 & $\mathbf{0 . 1 2 0 2 5}$ \\
\hline P12 & 0.08188 & 0.13184 & 0.13035 & 0.054387 & 0.045331 & $\mathbf{0 . 0 8 8 7 6}$ \\
\hline P13 & 0.03837 & 0.10024 & 0.11246 & 0.141512 & 0.042874 & $\mathbf{0 . 0 8 7 0 9}$ \\
\hline
\end{tabular}

Table 4. Significance of the problems

\begin{tabular}{c|c|c|c}
\hline Problem description & Occurrence, $\%$ & Influence to project, scores & $\begin{array}{c}\text { Problems significance } \\
\text { (Normalized values of criteria, } \%=100 \%)\end{array}$ \\
\hline P1 & 64.29 & 2.993 & $7.69 \%$ \\
\hline P2 & 92.86 & 2.804 & $7.20 \%$ \\
\hline P3 & 7.14 & 0.340 & $0.87 \%$ \\
\hline P4 & 42.86 & 3.011 & $7.74 \%$ \\
\hline P5 & 50 & 2.618 & $6.73 \%$ \\
\hline P6 & 50 & 3.918 & $10.07 \%$ \\
\hline P7 & 14.26 & 0.695 & $1.79 \%$ \\
\hline P8 & 50 & 6.655 & $17.10 \%$ \\
\hline P9 & 42.86 & 5.519 & $14.18 \%$ \\
\hline P10 & 50 & 3.397 & $8.73 \%$ \\
\hline P11 & 21.43 & 2.577 & $6.62 \%$ \\
\hline P12 & 21.43 & 1.902 & $4.89 \%$ \\
\hline P13 & 28.57 & 2.488 & $6.39 \%$ \\
\hline
\end{tabular}


the $C I$ value by the Random Index ( $R I)$ using the Eqn (3). $C R=0.0986<0.1$ it is less than $10 \%$, so the expert's inconsistency is acceptable.

The results of analysis (see Table 4):

- The top three problems with highest occurrence in the list (cover over $41 \%$ of all range) are: problem P8 (17.1\%), problem P9 (over 14.18\%), and problem P6 (over 10.07\%). Meanwhile, the biggest influence to the project by expert opinion (in scores) have problem P3 (2.41\%), problem P7 (2.23\%), also problems P4 and P6 (1.65\% and 1.60\%);

- Top six problems with highest occurrence in the list (cover over $66 \%$ of all range) are: problems P10 (8.73\%), problem P4 (7.74\%) and problem P1 (7.69\%);

- Problems P2 (Due to cost savings a feasibility study is not completed, technical and detail design is arranged in careless way) occurrence is $92,86 \%$ but it have little impact on the project, and does not fall into the top 6 problems;

- Average values for problems P5, P11, P12 and P13 (between values 4.89-6.73\%);

- Problem P3 (the technical staff of Client are unqualified and incompetent) gets only $0.87 \%$ of all importance evaluation but neither the less it has impact to successful project implementation.

The final results of analysis using the suggested problem recognition methodology are presented in Table 5. Significance of each problem is estimated considering analysis of statistical data as well as using decision-making methodology (AHP) and applying expert survey. All problems are prioritised, consequences listed and the best solutions are delivered in the last column of the table.

Based on the results of research and having identified the major problems and solutions related to BIM uses are introduced while implementing reconstruction projects. The initial graphical information and the 3D basis BIM models obtained with advanced computeraided survey techniques such as close-range photogrammetry and laser scanning. These advanced ICT solutions can be used during design and construction of any type of reconstruction project in residential, administrative, industrial, cultural heritage and even in the archaeology fields (Pepe et al. 2016). But the results show the need to improve theoretical knowledge and practical skills using BIM methodology for every project participant. And only after it is possible to implement the information management techniques to improve project procurement procedures and ensure effective reconstruction project. The BIM model will allow to analyse the current situation and develop new solutions and to find conflicts before reconstruction.

As successful examples of BIM uses in survey projects, the 3D point cloud model shown in Figure 3, it combined result made by terrestrial laser scanner and close range photogrammetry. This is an example of reconstruction project implemented in Vilnius, the capital and the largest business city in Lithuania. The reliable information and project team work based on BIM methodology can assure effective procedures and prevent occurrence of the most significant problems characteristic to reconstruction projects that are implemented in traditional way and without using information modelling and other digital technologies. The complex use of advanced Computer-Aided tools and BIM is the best solution on site.

The systematic solution to solve the problems with information management in reconstruction projects is suggestion to have a Common Data Environment (CDE) complying to BS 1192-2007 standard for quick information sharing to all participants in the project. This methodology determines how to manage the construction information, including the use of BIM modelling and CAD systems. It distributes and collaborates systematic BIM process and clearly defines BIM and CAD data naming policy. Coordination between designers, contractors and
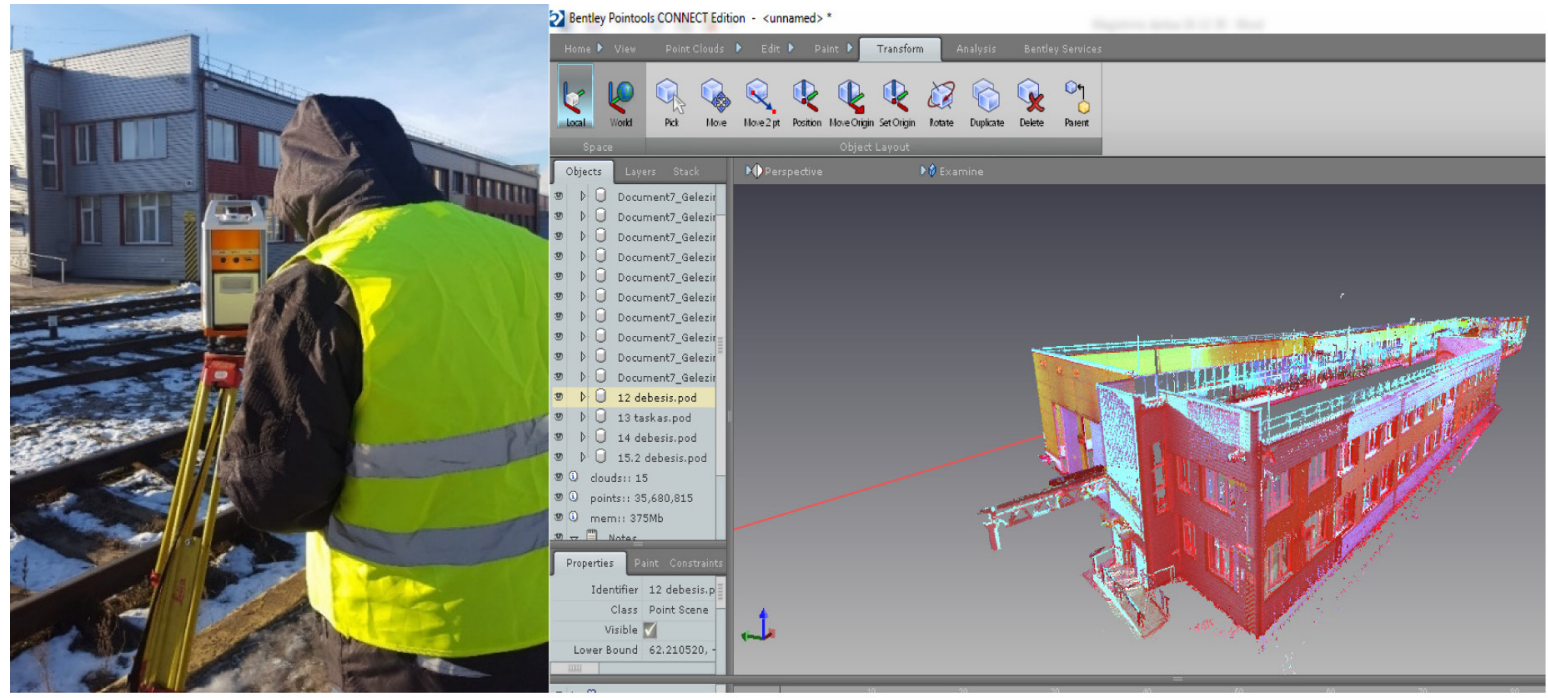

Fig. 3. BIM uses in reconstruction project: a Lithuanian case study (laser scan and model) 
Table 5. Prioritised problems, consequences and solutions

\begin{tabular}{|c|c|c|c|}
\hline Index & Problem & Consequence & Solution \\
\hline P8 & $\begin{array}{l}\text { Incompetent contractor } \\
\text { team, do not evaluated } \\
\text { complexity and continuity } \\
\text { of works. }\end{array}$ & $\begin{array}{l}\text { - Delay in starting work; } \\
\text { - Non-compliance with the work schedule; } \\
\text { - Decreased quality of work; } \\
\text { - Customer downtime and project delays; } \\
\text { - Penalties and fines. }\end{array}$ & $\begin{array}{l}\text { - Use multiple criteria by setting the } \\
\text { winner of the contest; } \\
\text { - Apply Employer's Information } \\
\text { Requirements preparing the } \\
\text { procurement documents. }\end{array}$ \\
\hline P9 & $\begin{array}{l}\text { The bad preparation of } \\
\text { technical design. }\end{array}$ & $\begin{array}{l}\text { - Errors in procurement and construction works; } \\
\text { - The contractor is selected according to an } \\
\text { improperly designed technical project; } \\
\text { - Increase of the project execution time and } \\
\text { duration; } \\
\text { - The Contractor must use additional funds to } \\
\text { carry out work design and contract works; } \\
\text { - Additional funds needed; } \\
\text { - Impair quality. }\end{array}$ & $\begin{array}{l}\text { - The use of BIM tools; } \\
\text { - The adoption of project solutions } \\
\text { before the design stage; } \\
\text { - Integrated cooperation between } \\
\text { project participants; } \\
\text { - The integrity of the technical and } \\
\text { work project; } \\
\text { - Determining the level of detail at } \\
\text { each stage. }\end{array}$ \\
\hline P6 & $\begin{array}{l}\text { Unqualified and incompe- } \\
\text { tent design team, unable } \\
\text { to evaluate time of design } \\
\text { works. }\end{array}$ & $\begin{array}{l}\text { - Delays in project coordination and correction } \\
\text { work; } \\
\text { - Delay in obtaining a building permit; } \\
\text { - Delay in procurement of works; } \\
\text { - Penalties and fines. }\end{array}$ & $\begin{array}{l}\text { - Apply Employer's Information } \\
\text { Requirements preparing the } \\
\text { procurement documents; } \\
\text { - Using many criteria by setting the } \\
\text { winner of the contest. }\end{array}$ \\
\hline P10 & $\begin{array}{l}\text { Work repair during con- } \\
\text { struction. }\end{array}$ & $\begin{array}{l}\text { - Long decision-making time; } \\
\text { - Occurrence of downtime; } \\
\text { - Delay in contract work. }\end{array}$ & $\begin{array}{l}\text { - Raise qualification (client, employ- } \\
\text { er, designer, contractor); } \\
\text { - Definition of the responsibility; } \\
\text { - Change of staff; } \\
\text { - Integrated cooperation. }\end{array}$ \\
\hline $\mathrm{P} 4$ & $\begin{array}{l}\text { Long duration of procure- } \\
\text { ment and purchasing pro- } \\
\text { cedures takes long time. }\end{array}$ & $\begin{array}{l}\text { - Delays in the project and the desired end } \\
\text { result; } \\
\text { - Increase of the sale loses. }\end{array}$ & $\begin{array}{l}\text { - Application of BIM measures to } \\
\text { speed up purchasing procedures; } \\
\text { - Use of internal company standards, } \\
\text { according to foreign practice. }\end{array}$ \\
\hline $\mathrm{P} 1$ & $\begin{array}{l}\text { The documentation of the } \\
\text { reconstructed building } \\
\text { is out of date or not- } \\
\text { existent. }\end{array}$ & $\begin{array}{l}\text { - Improperly prepared specification and design; } \\
\text { - Error repair during contract work; } \\
\text { - Preparation of a detailed work project; } \\
\text { - Work delays and increased project costs; } \\
\text { - The building maintenance has not started; } \\
\text { - Penalties and fines. }\end{array}$ & $\begin{array}{l}\text { - Execute project according to IPD } \\
\text { (Integrated project delivery) con- } \\
\text { tract type; } \\
\text { - Use of digital photogrammetry and } \\
\text { laser scanning tools for generating } \\
\text { information. }\end{array}$ \\
\hline $\mathrm{P} 2$ & $\begin{array}{l}\text { Due to cost savings a } \\
\text { feasibility study is not } \\
\text { completed, technical and } \\
\text { detail design is arranged } \\
\text { in careless way. }\end{array}$ & $\begin{array}{l}\text { - Delay in obtaining a construction permit, } \\
\text { which increases the duration of the project } \\
\text { execution. }\end{array}$ & $\begin{array}{l}\text { - Assign responsibilities and reduce } \\
\text { the number of responsible people; } \\
\text { - To use a common data environment } \\
\text { for collaboration. }\end{array}$ \\
\hline P5 & $\begin{array}{l}\text { Every project is being } \\
\text { coordinated involving a } \\
\text { number of participants. }\end{array}$ & $\begin{array}{l}\text { - Extending project coordination time; } \\
\text { - Latency and delays. }\end{array}$ & $\begin{array}{l}\text { - Assign responsibilities and reduce } \\
\text { the number of responsible people; } \\
\text { - To use a common data environment } \\
\text { for collaboration. }\end{array}$ \\
\hline P11 & Delay in Decision making. & $\begin{array}{l}\text { - Long decision-making time; } \\
\text { - Occurrence of downtime; } \\
\text { - Project delays. }\end{array}$ & $\begin{array}{l}\text { - Raise qualification (client, employ- } \\
\text { er, designer, contractor); } \\
\text { - Definition of the response limit; } \\
\text { - Change of project staff. }\end{array}$ \\
\hline P13 & $\begin{array}{l}\text { Correction of errors during } \\
\text { warranty period. }\end{array}$ & $\begin{array}{l}\text { - Bankruptcy of the company that carried out } \\
\text { construction work; } \\
\text { - No liability and warranty. }\end{array}$ & $\begin{array}{l}\text { - Regulation of the legal basis; } \\
\text { - Insurance payments; } \\
\text { - As-build model for maintenance. }\end{array}$ \\
\hline $\mathrm{P} 12$ & $\begin{array}{l}\text { Extension of project } \\
\text { execution time. }\end{array}$ & $\begin{array}{l}\text { - Additional operating costs for contractors; } \\
\text { - Delay in operation: production downtime, this } \\
\text { is due the downtime of the customer. }\end{array}$ & $\begin{array}{l}\text { - Preparation of the integrated } \\
\text { project; } \\
\text { - Use of BIM tools. }\end{array}$ \\
\hline P7 & $\begin{array}{l}\text { There is no information } \\
\text { continuity. }\end{array}$ & $\begin{array}{l}\text { - Re-collecting information; } \\
\text { - Waste the funds. }\end{array}$ & $\begin{array}{l}\text { - Common data environment for } \\
\text { collaboration; } \\
\text { - Defined documentation archiving. }\end{array}$ \\
\hline P3 & $\begin{array}{l}\text { The technical staff of } \\
\text { Client are unqualified and } \\
\text { incompetent (low skill } \\
\text { and knowledge level). }\end{array}$ & $\begin{array}{l}\text { - The technical project purchase contract are } \\
\text { formulated incorrectly, incomprehensibly to } \\
\text { designers and contractors. }\end{array}$ & $\begin{array}{l}\text { - Raise qualification of employees; } \\
\text { - New staff selection; } \\
\text { - Recruiting a BIM manager. }\end{array}$ \\
\hline
\end{tabular}


operators in the BIM project should be ensured during preparation of the project. The data is finely divided and structured to facilities inside the CDE. This enables to produce traditional drawings and documents from CDE. This way provides greater control of data revisions and versions. The use of structured CDE requires the discipline of all project team members to follow BIM procedures. The BIM model improves collaboration between participants and the information from the BIM model is available to all project team members to support decision making before works have been started.

\section{Conclusions}

It is identified that the significances of the following problems have the major impact to the reconstruction project efficiency and results: $17.10 \%$ - problem P8 (incompetent contractor team); $14.18 \%$ - problem P9 (the bad preparation of technical design); $10.07 \%$ - problem P6 (unqualified and incompetent design team). The low competence can be improved with experience in BIM uses. The project management can be solved using ICT tools. The BIM model allow to analyse the current situation, develop new solutions, to find conflicts before actual reconstruction works, improve supply chain, management, planning and the quality of reconstruction. The initial lack of information can be solved using digital photogrammetry and laser scanning tools. The problems with information management can be solved using team based collaboration between project participants and integrated project delivery, establish Common Data Environment, and initiate use BIM based procurement. The BIM model according to BIM standard requires: to build a team, prepare BIM model and use/update BIM model during all project life-cycle stages. The reconstruction model according to BIM standard can reduce the project risks and can provide more accurate information to support decision making process.

\section{References}

Barbosa, M. J.; Pauwels, P.; Ferreira, V.; Mateus, L. 2016. Towards increased BIM usage for existing building interventions, Structural Survey 34(2): 168-190. https://doi.org/10.1108/SS-01-2015-0002

Brito, D. M.; Ferreira, E. A. M. 2015. Strategies for representation and analyses of 4D modeling applied to construction project management, Procedia Economics and Finance 21: 374-382. https://doi.org/10.1016/S2212-5671(15)00189-6

Di Giuda, G. M.; Villa, V.; Piantanida, P. 2015. BIM and energy efficient retrofitting in school buildings, Energy Procedia 78: $1045-1050$. https://doi.org/10.1016/j.egypro.2015.11.066

Eadie, R.; Browne, M.; Odeyinka, H.; McKeown, C.; McNiff, S. 2013. BIM implementation throughout the UK construction project lifecycle: An analysis, Automation in Construction 36: 145-151. https://doi.org/10.1016/j.autcon.2013.09.001

Erdogan, S. A.; Saparauskas, J.; Turskis, Z. 2017. Decision making in construction management: AHP and expert choice approach, Procedia Engineering 172: 270-276. https://doi.org/10.1016/j.proeng.2017.02.111
Kutut, V.; Zavadskas, E. K.; Lazauskas, M. 2014. Assessment of priority alternatives for preservation of historic buildings using model based on ARAS and AHP methods, Archives of Civil and Mechanical Engineering 14(2): 287-294. https://doi.org/10.1016/j.acme.2013.10.007

Lam, T.; Mahdjoubi, L.; Mason, J. 2017. A framework to assist in the analysis of risks and rewards of adopting BIM for SMES in the UK, Journal of Civil Engineering and Management 23(6): 740-752. https://doi.org/10.3846/13923730.2017.1281840

Lin, Y. C.; Chang, J. X.; Su, Y. C. 2016a. Developing construction defect management system using BIM technology in quality inspection, Journal of Civil Engineering and Management 22(7): 903-914. https://doi.org/10.3846/13923730.2014.928362

Lin, Y. C.; Lee, H. Y.; Yang, I. T. 2016b. Developing as-built BIM model process management system for general contractors: a case study, Journal of Civil Engineering and Management 22(5): 608-621. https://doi.org/10.3846/13923730.2014.914081

Lu, Q.; Won, J.; Cheng, J. C. P. 2016. A financial decision making framework for construction projects based on 5D Building Information Modeling (BIM), International Journal of Project Management 34(1): 3-21. https://doi.org/10.1016/j.ijproman.2015.09.004

Migilinskas, D.; Balionis, E.; Džiugaitè-Tumėnienè, R.; Šiupšinskas, G. 2016. An advanced multi-criteria evaluation model of the rational building energy performance, Journal of Civil Engineering and Management 22(6): 844-851. https://doi.org/10.3846/13923730.2016.1194316

Migilinskas, D.; Ustinovichius, L. 2006. Computer-aided modelling, evaluation and management of construction projects according to PLM concept, Lecture Notes in Computer Science, Cooperative Design, Visualization, and Engineering 4101: 242-250.

Mill, T.; Alt, A.; Liias, R. 2013. Combined 3D building surveying techniques terrestrial laser scanning (TLS) and total station surveying for BIM data management purposes, Journal of Civil Engineering and Management 19(Suppl 1): 23-32. https://doi.org/10.3846/13923730.2013.795187

Pavlovskis, M.; Antucheviciene, J.; Migilinskas, D. 2016. Application of MCDM and BIM for evaluation of asset redevelopment solutions, Studies in Informatics and Control 25(3): 293-302. https://doi.org/10.24846/v25i3y201603

Pepe, M.; Ackermann, S.; Fregonese, L.; Achille, C. 2016. 3D Point cloud model color adjustment by combining terrestrial laser scanner and close range photogrammetry datasets, International Journal of Computer, Electrical, Automation, Control and Information Engineering 10(11): 1918-1924.

Popov, V.; Juocevicius, V.; Migilinskas, D.; Ustinovichius, L.; Mikalauskas, S. 2010. The use of a virtual building design and construction model for developing an effective project concept in 5D environment, Automation in Construction 19(3): 357-367. https://doi.org/10.1016/j.autcon.2009.12.005

Rasiulis, R.; Ustinovichius, L.; Migilinskas, D.; Cepurnaite, J.; Virbickas, A. 2015. Energy efficiency of a public building renovation and reconstruction using base model passive house and BIM technology, Engineering Structures and Technologies 7(3): 114-125. https://doi.org/10.3846/2029882X.2016.1123896

Saaty, T. L. 1980. The analytic hierarchy process. New York: McGraw-Hill.

Saaty, T. L.; Figueira, J.; Greco, S.; Ehrgott, M. 2005. The analytic hierarchy and analytic network processes for the measurement of intangible criteria and for decision-making, in Multiple criteria decision analysis: State of the art surveys. Springer, 345-408. 
Sun, C.; Jiang, S.; Skibniewski, M. J.; Man, Q.; Shen, L. 2015. A literature review of the factors limiting the application of BIM in the construction industry, Technological and Economic Development of Economy 23(5): 764-779. https://doi.org/10.3846/20294913.2015.1087071

Ustinovichius, L.; Peckienė; A.; Popov, V. 2017. A model for spatial planning of site and building using BIM methodology, Journal of Civil Engineering and Management 23(2): 173-182. https://doi.org/10.3846/13923730.2016.1247748

Volk, R.; Stengel, J.; Schultmann, F. 2014. Building Information Models (BIM) for existing buildings - literature review and future needs, Automation in Construction 38: 109127. https://doi.org/10.1016/j.autcon.2013.10.023
Xian, S.; Chen, H. 2015. Revitalisation of industrial buildings in Hong Kong: New measures, new constraints?, Habitat International 47: 298-306. https://doi.org/10.1016/j.habitatint.2015.02.004

Zavadskas, E. K.; Antucheviciene, J; Turskis, Z., Adeli, H. 2016. Hybrid multiple-criteria decision-making methods: A review of applications in engineering, Scientia Iranica. Transaction A, Civil Engineering 23(1): 1-20.

Zhao, X. 2017. A scientometric review of global BIM research: Analysis and visualization, Automation in Construction 80: 37-47. https://doi.org/10.1016/j.autcon.2017.04.002

Darius MIGILINSKAS. Associate professor at Department of Construction Technology and Management, Vilnius Gediminas Technical University. Doctor of Technological Sciences (Civil Engineering 02T) in VGTU, 2010. Publications: the author and co-author of over 45 research papers in international scientific journals and international conferences. Research interests: new technologies and management of construction works; PLM and BIM modelling in Civil Engineering; uncertainty and risk management; game theory in construction's decision making; sustainable development and energy efficiency in buildings.

Miroslavas PAVLOVSKIS. PhD student of Construction Technology and Management at Vilnius Gediminas Technical University. Publications: the author and co-author of 5 research papers in scientific journals and international conferences. Research interests: sustainable development, new construction technologies, BIM modelling, urban redevelopment.

Irina URBA. MSc student of Reinforced Concrete and Masonry Structures at Vilnius Gediminas Technical University. Publications: the author and co-author of 1 research paper in scientific journal. Research interests: reconstruction, BIM, industrial buildings, life cycle of the project.

Viačeslav ZIGMUND. MSc student of Reinforced Concrete and Masonry Structures at Vilnius Gediminas Technical University. Publications: the author and co-author of 1 research paper in scientific journal. Research interests: reconstruction, BIM, veneer façade systems, project management. 